\title{
Contribution of tourism to diversification and development of a green economy
}

\author{
Olga Brel $^{1}$, Anna Zaytseva ${ }^{1, *}$, and Phillip Kaizer ${ }^{1}$ \\ ${ }^{1}$ Kemerovo State University, Department of Geology and Geography, 650000, Krasnaya Street, 6, \\ Kemerovo, Russia
}

\begin{abstract}
In the current economic situation, the solution to the problems of diversification of mining regions is relevant not only in terms of economic outcome, but also the need to change the ecological situation in industrial regions towards its improvement. Diversification of the region's economy is associated with the idea of expanding the range of economic activities and considered as a mechanism to reduce risks and monodependence of the regional economy. The study suggests that tourism could become one of the areas of diversification and greening of the mining region economy by the example of the Kemerovo region. The structure of the GRP and individual indicators characterizing the state of the tourism sector were analyzed to assess the impact of tourism on the diversification of the economy of the Kemerovo region. Despite the fact that the total share of the tourism sector has changed slightly over the 5 years, its multiplier effect has a positive impact on the state of the service sector and the economy of the entire region. It was confirmed by the results of the analysis. The optimistic scenario for the development of the Kemerovo region determines the large role of tourism in the diversification and greening of the region's economy. The implementation of the conservative scenario that provides the supportive development of traditional sectors, does not exclude opportunities for the development of tourism, which will ensure the effective and long-term sustainable development of the Kuzbass.
\end{abstract}

\section{Introduction}

The problem of diversifying the economy of mining regions has become more and more urgent over the past years. It is a priority strategic direction for the development of the country, not just for a separate region. Proper implementation of a diversification policy, as a rule, contributes to the manifestation of positive effects for the region, such as increasing GRP, population incomes and export capital, creating of high-tech jobs, decreasing in unemployment, reducing production costs, as well as the development of small and medium-sized businesses.

The "term diversification" was originally applied to the strategic analysis of corporations and denoted their development strategy, focused on smoothing the risks

\footnotetext{
*Corresponding author: lit-ani@mail.ru
} 
occurring in the domestic or foreign economic markets [1]. The application of the principles of diversification on the scale of the country's economy gives more advantages, since it allows to maximize the use of its natural resources together with new opportunities for economic growth, which in turn leads to lower operating costs and increase national competitiveness [2]. Regarding to the regions' economies, it is proposed to interpret the term "diversification" as a comprehensive development of their economies, expanding the scope of regional production activities, overcoming the risks associated with external economic conditions, and also reducing the commodity dependence [1].

A high level of urbanization, together with an intense concentration of production structures in cities and urban agglomerations, difficult ecological situation in these territories are the main characteristics of mining regions. However, over time, organizational structures have become very resistant to the need for institutional change in many such regions. It was particularly evident in countries with transition economies, where such regions were under direct state control for a long time, ensuring the extremely monopolistic position of industrial enterprises on the market [3, 4]. The long monodependence of mining regions on one type of energy resources, their multiplicative effect on the economy, direct government control over the production volume and pricing became an obstacle to the subsequent diversification of the economy and improving the environmental situation in these regions. In the future, this may cause the participation of mining regions in global economic competitiveness to be difficult. And this, in turn, will negatively affect their starting positions in any other sector of the economy (finance, telecommunications, biotechnology, digital technologies, tourism, etc.).

It is important to understand that diversification of the regional economy is a very complex and long-term process that requires the use of significant amounts of resources for its implementation. Therefore, problems primarily related to economic feasibility, determining directions and assessing the consequences of the economy diversification in a particular region arise. The strategy of diversification of the regional economy can be manifested in stimulating the development of those types of activities whose products are characterized by low material consumption, the use of reproducible resources and high added value. Among these activities is tourism of course.

Many countries, as well as their individual entities, have natural and cultural resources suitable for tourism development. Due to the fact that tourism is the third largest industry in the world (immediately after the oil and automobile industries), in accordance with the amount of income generated, they consider this activity as a strategic direction for their "green" economic development [5-7].

Kemerovo region (Kuzbass) is a typical mining regionю Its economy is based on export-oriented coal industry. Kuzbass coal accounts for $58 \%$ of the volume of production in the Russian Federation. This fact is also can be confirmed by the A.G. Granberg's approach, according to which all regions can be divided into several groups. Mining regions group includes those with a share of gross value added in the category of "Mining" higher than the share of "Manufacturing". So, for the Kemerovo region these values in 2018 were $36.7 \%$ and $17.1 \%$, respectively.

It is important to note that $70 \%$ of the region's population lives in cities and urban-type settlements, which depend on one industry: coal, mining, metallurgy, etc. As a result, the region has acquired an industrial external and internal image. The toponym Kuzbass (the Kuznetsk coal basin, proposed by geologist P. A. Chikhachev in the 19th century) became the second official name of the Kemerovo region, although the borders of the Kuznetsk coal basin do not coincide with the administrative boundaries of the region [8]. And both these titles became the official synonyms only in December 21, 2018 [9].

Despite its obvious industrial specialization, Kuzbass has great potential for the development of various types of tourism based on existing historical, cultural and natural 
recreational resources. In this case, the development of the tourism industry will be more cost-effective compared to the situation when these resources need to be created. Moreover, tourism should be considered as a catalyst for the regional economy and its greening, which allows not only to use the entire range of recreational resources existing in the region, but also to use the combined potential of the territory in the most efficient way. Tourism development is often referred to as the most suitable option for diversifying resourcedependent regions, and for balancing the negative effects of economic restructuring. Thus, for peripheral mining regions, tourism can be seen as a relatively simple way to overcome the previous ways of developing an economy based on industry $[10,11]$.

\section{Materials and methods}

Theoretical and methodological foundations of diversification of the region's economy are presented in the works of domestic and foreign scientists. Their work is mainly devoted to issues such as the study of economic growth problems, the study of trends and signs of diversification, measures of diversification level and risk assessment. However, various and sometimes conflicting views on the problem of measuring the diversification level are often found. This is especially true for different types of countries and regions and is most relevant for industrial regions, whose economy has traditionally been based on extractive industries.

The study started off with the hypothesis that not every mining region is able to provide long-term sustainable development of tourism on its territory. This is due not only to the lack of valuable recreational resources, but also to the narrow industrial specialization of a number of regions. The question arises: is it worth developing tourism in regions that are sufficiently developed at the expense of industry? But, if the mining region has a rich tourist and recreational potential, then why not use it as a source of additional financial income to the economy?

To study this issue, the authors conducted a comparative analysis of some indicators characterizing the state of the tourism industry, using statistical methods, methods of information search, generalization, synthesis and analysis. Data from the Federal State Statistics Service for the Kemerovo Region, as well as official documents and publications of other authors have become the main base and materials for the study.

Data analysis made it possible to note that the share of the mining industry in the region's GRP is growing annually, as evidenced by the data from 2014 to 2018 (Fig. 1). Growth amounted to about $70 \%$ over 5 years. There is no doubt that this growth will continue which is confirmed by the strategy for socio-economic development of the Kemerovo region until 2035 [12].

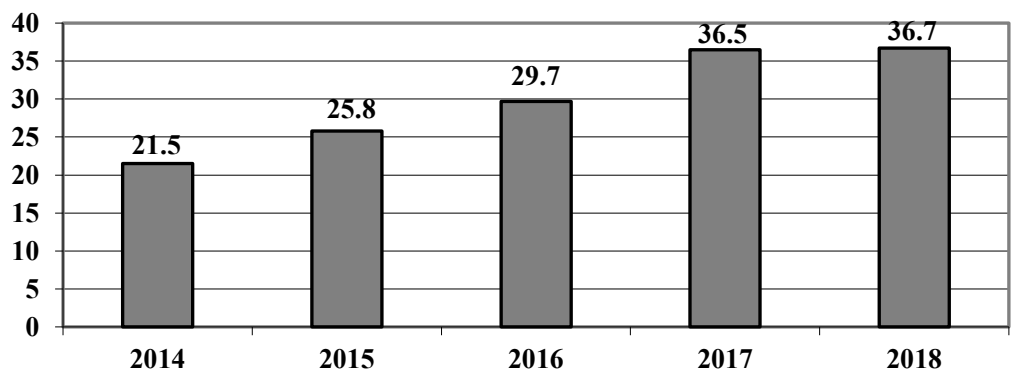

Fig. 1. The share of "Mining" in the structure of the GRP of the Kemerovo region, \%. 
The regional authorities continue to look for ways out of commodity dependence in the direction of activating the potential of other industries despite the increase in the level of mineral extraction in the region, an increase in its share in the region's GRP, and, as a consequence, the impossibility of quickly replacing industry with other sectors of the economy. In addition, a number of researchers note that there are steady positive trends in socio-environmental and economic development in the Kemerovo region in recent years, which is confirmed by official statistics. This is not only an increase in the amount of coal and GRP production per capita, but also a decrease in GRP energy intensity, stabilization of atmospheric emissions, improvement of the "quality of investments", etc. [13].

A focus on sustainable development based on key initiatives of the regional authorities: "Clean Coal - Green Kuzbass" and "Healthy People in the Industrial Region" is one of the latest economic trends in the Kemerovo region. The Scientific and Educational Center (REC) "Kuzbass", established in the Kemerovo Region in 2019 to develop strategies and programs for the further development of the region, in fact, combined these two initiatives, and set the goal of further development of the region to achieve world leadership in the field of:

exploration, efficient mining, transportation and deep processing of solid minerals;

mining engineering;

integrated river basin management;

application of convergent and nature-like technologies;

production of clean energy while reducing the anthropogenic load and risks to humans, etc. [14].

Clean coal technologies, integrated processing of low-grade coal and coal-enrichment waste, robotic systems for mining operations, improving the efficiency of transportation of minerals, creating waste-free natural technologies, genetic biotechnologies for health conservation, infrastructure revolution, etc. are among mechanisms for achieving the goal of world leadership in mentioned fields.

One of the problems of mining regions as well as Kuzbass is to find a balance between the need to expand the area and volume of mineral extraction and preserve a comfortable environment for human habitation and the implementation of the key initiative-a healthy person in an industrial region, including by satisfying his recreational needs. In this regard, the emphasis in the diversification of economic activity in the region is made, among other things, on the development of the cultural cluster of Kuzbass, as well as tourism, which is necessary to create alternative ways of development of the region and is considered as an additional source of cash flows to the economy of Kuzbass.

Statistical data on the structure of GRP, the volume and structure of paid services to the population, directly or indirectly related to the tourism industry in the period from 20142018 were collected and analyzed by the authors. During the study the authors encountered difficulties in determining the impact of tourism on the region's economy caused by the imperfection of statistical accounting of economic indicators of the tourism industry. So, for example, it is difficult to calculate the total number of tourist arrivals and expenses, because official statistics only consider persons registered in hotels and similar accommodation facilities, and does not take into account those who use private guest houses for accommodation. Tourism as a separate industry is not allocated at all in the GRP structure. However, a number of provisions are not in doubt and are used everywhere in analytical studies despite all the differences in the methodology for determining the economic effect of tourism activities.

In this regard, GRP produced in the tourism sector, calculated per capita, is an important indicator characterizing the level of tourism development and its role in the region's economy (Table 1). 
Table 1. GRP and GRP per capita trends reflecting diversification processes in Kemerovo region [15].

\begin{tabular}{|l|c|c|c|c|c|}
\hline \multicolumn{1}{|c|}{ Indicator } & $\mathbf{2 0 1 4}$ & $\mathbf{2 0 1 5}$ & $\mathbf{2 0 1 6}$ & $\mathbf{2 0 1 7}$ & $\mathbf{2 0 1 8}$ \\
\hline Population & 2734075 & 2724990 & 2717627 & 2708844 & 2694877 \\
\hline GRP (mln.rub.) & 752024000 & 843345400 & 865325300 & 1058430400 & 1241598600 \\
\hline $\begin{array}{l}\text { GRP per capita } \\
\text { (thous. rub.) }\end{array}$ & 275056,1 & 309485,7 & 318412,1 & 390731,4 & 460725,5 \\
\hline $\begin{array}{l}\text { Paid services } \\
\text { directly or } \\
\text { indirectly related } \\
\text { to tourism (thous. } \\
\text { rub.) }\end{array}$ & 9170155.7 & 9334788.5 & 8768737.8 & 9041345.7 & 9414401.2 \\
\hline $\begin{array}{l}\text { GRP produced in } \\
\text { the tourism per } \\
\text { capita (thous. } \\
\text { rub.) }\end{array}$ & 3354,0 & 3425,6 & 3226,6 & 3337,7 & 3493,4 \\
\hline
\end{tabular}

Also, the authors determined the volume and structure of paid services, including those directly or indirectly related to tourism as an indicator that most clearly characterizes the role of tourism in the region's economy (Table 2).

Table 2. The volume and structure of paid services, 2014-2018 (thousand rubles) [15].

\begin{tabular}{|l|c|c|c|c|c|}
\hline \multicolumn{1}{|c|}{ Indicator } & $\mathbf{2 0 1 4}$ & $\mathbf{2 0 1 5}$ & $\mathbf{2 0 1 6}$ & $\mathbf{2 0 1 7}$ & $\mathbf{2 0 1 8}$ \\
\hline $\begin{array}{l}\text { Volume of paid } \\
\text { services - total }\end{array}$ & $\begin{array}{c}91909 \\
\text { of which: }\end{array}$ & 97233607.8 & 101303651.6 & 109795061.3 & 116987497.4 \\
\hline $\begin{array}{l}\text { Paid services } \\
\text { directly or } \\
\text { indirectly } \\
\text { related to } \\
\text { tourism }\end{array}$ & 9170155.7 & 9334788.5 & 8768737.8 & 9041345.7 & 9414401.2 \\
\hline of which: & 1506725.5 & 1398565.2 & 1051812.9 & 1160065 & 1052159.3 \\
\hline $\begin{array}{l}\text { Health and } \\
\text { Wellness }\end{array}$ & 4376929.8 & 4256527.7 & 3884755.6 & 4010471.9 & 4116878.8 \\
\hline $\begin{array}{l}\text { Tourist and } \\
\text { excursion }\end{array}$ & 1086808.4 & 1157910.9 & 1273120.9 & 1344497.5 & 1339574.5 \\
\hline $\begin{array}{l}\text { Accommodation } \\
\text { (hotels and } \\
\text { motels) }\end{array}$ & 1347730.7 & 1519497.3 & 1490112.2 & 1425064.9 & 1644622.8 \\
\hline $\begin{array}{l}\text { Cultural } \\
\text { establishment }\end{array}$ & 851961.3 & 1002287.4 & 1068936.2 & 1101246.4 & 1261165.8 \\
\hline Sport and PE & & & & & \\
\hline
\end{tabular}

The expansion of economic activities in the region, avoiding mono-dependence positively affects the development of the economy as a whole. However, the most important issue for the region is how tangible will be the contribution of tourism to regional development and whether this contribution will affect the population well-being, its employment, improving living standards, etc.

\section{Results and discussion}

An analysis of the GRP structure of the Kemerovo region indicates a low level of diversification of its economy and dominant industrial specialization. Thus, the share of extractive industries in the structure of GRP increased by $15.2 \%$ - from 21.5 to 36.7 over 5 years.

In this study, the authors proceeded from the proposition of a direct relationship between the value of GDP per capita and the level of diversification: the higher the value of GRP per capita, the greater the level of diversification of the region's economy. For the 
analyzed period, the GRP per capita has increased by almost $40 \%$, while the GRP produced in the tourism sector, calculated per capita, only by 4\%. Analysis of literary sources [16-18] showed that regions specializing in the extraction of minerals, including Kemerovo region, demonstrate a higher growth of GRP per capita, but due to the development of extractive industries. On the other hand, the development of the manufacturing industry, the service sector, the increase in their role in GRP per capita may change slightly - in the case of the Kemerovo region only $+4 \%$ over 5 years. During the analyzed period, the share of services directly or indirectly related to tourism in the total volume of paid services decreased from 9.9 in 2014 to $8 \%$ in 2018 . The share of tourism industry in the total volume of GRP has also decreased from 1.2 to $0,75 \%$. This paradox may serve as an obstacle to further diversification of the region's economy, as not reflected in the changing role of other industries in the structure of the GRP, in particular tourism. In this case, we can only talk about the presence of trends towards diversification, which is confirmed by the growth in the volume of paid services, including directly or indirectly related to tourism (Fig. 2).

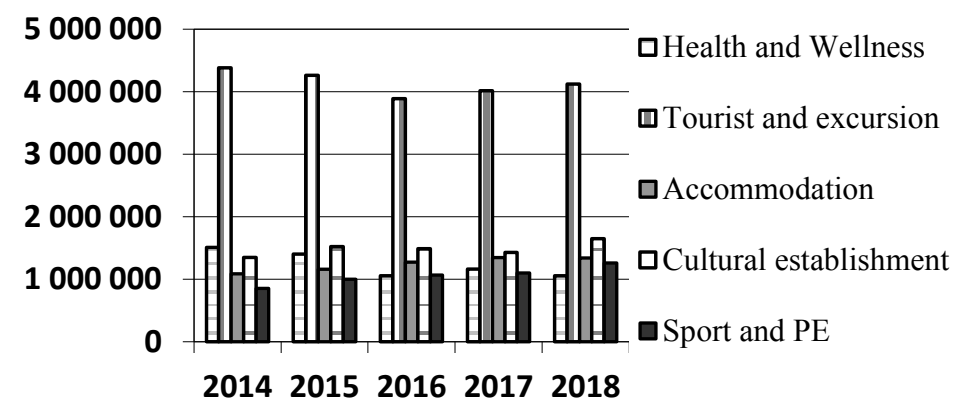

Fig. 2. Dynamics of individual indicators of the volume of paid services, thousand rubles.

An analysis of the data presented in the fig. 2 indicates small changes over the years, but in general, all selected indicators are relatively stable for the region. The total volume of paid services has increased by $27 \%$ for the analyzed period. Meanwhile the volume of paid services directly or indirectly related to tourism increased only by $3 \%$.

The activities of tourist companies, leisure organizations, tourist and excursion bureaus and centers are included in total volume of tourist and excursion services. They traditionally bring the greatest income to the regions' economy. Kuzbass is no exception. Fig. 2 indicates that after a significant decrease in the volume of tourist and excursion services in 2016 a positive trend has been outlined in the next two years, but a negative trend has still remained $(-6 \%)$.

The volume of accommodation facilities services has increased by $23 \%$ for the analyzed period, while the volume of specialized accommodation facilities services decreased significantly $(-30 \%)$. In our opinion, this can be explained by the increase in the number of collective accommodation facilities, on the one hand, and the strengthening of the position of spa holidays in the neighboring regions (Altai region, Altai Republic, Republic of Khakassia), which mainly specialize in providing these services - on the another hand.

At the same time, services related to sports and physical exercises showed a noticeable increase $(+48 \%)$. This group of services includes such types of activities as the organization and conducting of sports, physical education and health events, competitions, camping trips, fishing and other individual and public events; rental of sports equipment, clothes and shoes; entrance tickets and season tickets for sports competitions and entertainment events; using of water parks, ski slopes and ski lifts, etc. The volume of paid services provided by cultural institutions also shows a noticeable positive trend $(+22 \%)$.

Thus, the analysis of the volume of paid services and its dynamics for the analyzed period indicates its significant growth. Despite the fact that tourist and excursion services 
for the entire period show negative dynamics, their multiplier effect has a positive impact on the state of the entire service sector. The diversification effect of tourism is also revealed in stimulating the country's economic growth and accelerating regional development, increasing tax revenues, creating new jobs, improving the quality of life of the local population through the manifestation of positive economic and social effects. The employment multiplier is of particular importance, since the number of available and newly created jobs is one of the most important indicators of the industry's contribution to the economy.

\section{Conclusions}

The dominance of one or several industries for mining and primary processing of minerals leads to instability in regional economic development, due to the dependence on modification in the economy structure under the influence of technological changes and state policy in resource-mining and processing industries, on changes in prices of primary resources and processed products. A diversified regional economy is a multilaterally developed, relatively resistant to economic crises, diversified economy in which one component replaces, complements or even compensates for other components in the event of a crisis.

From a practical point of view diversification of the regional economy is associated with the implementation of development models for certain types of economic activity. At the regional level, diversification is transforming into a qualitatively new category, causing the emergence of such positive effects as the creation of new jobs and a decrease in unemployment, which, in turn, leads to a relaxation of social tension, which is especially true for mining regions. For a region with an economy oriented towards mining industries the development of economic activities in the service sector may become one of the ways of solving socio-economic problems.

Kemerovo region, being a developed mining region, has a rich resource base for the development of tourism despite the fact that its GRP is mainly formed by mining and coal industry. Its historical, cultural and natural resources can be used to develop various types of tourism. Despite the fact that the analysis presented in this paper did not reveal any obvious structural shifts in the region's economy, the observed changes in individual indicators characterizing the state of the tourism sector indicate the presence of certain diversification trends.

The authors believe that for the Kemerovo region the conservative scenario focused on supporting development of traditional sectors, provided with modern means of production will remain a priority in the near future. At the same time the development of such an alternative industry as tourism is possible even with the implementation of this scenario, despite its vulnerability and dependence on a number of external and internal factors. It is obvious that tourism will not replace the resource-extracting sectors of the region, but will make a significant contribution to its economy. The impact of tourism will appear in the environment improvement, changing the quality of population life, its cultural level, contributing to the solution of a number of socio-economic and ecological problems, etc. Diversification of the mining region's economy due to the development of the tourism and related industries contributes to increasing tax revenues from business entities and increasing its investment attractiveness. Tourism facilitates innovation and the opening of new businesses in other sectors of the economy. The development of tourism will not only allow expanding the list of products manufactured in the region, but also radically modifies the image of the region from industrial to tourist, making it recognizable and unique. The demand for a range of services caused by tourism requires their reproduction, which in turn leads to the development of industries producing consumer goods: souvenir products, local 
crafts, etc. The region's own identity will allow it to be identified among the many mining regions of Russia, reflecting the specifics and nature of its economic and social development. This, in turn, can contribute to the development of traditional and an increase in the number of qualitatively new types of economic activity, and will also help to ensure the effective and long-term sustainable development of the Kuzbass.

\section{References}

1. N. Mikheeva, Diversification of regional economic structure as growth strategy, Regional Research of Russia 7(4), 30 (2017)

2. O. J. Suberu, et al., Diversification of the Nigerian economy towards a sustainable growth and economic development, Int. J. of Economics, Finance and Management sciences 3.2, 107 (2015)

3. L. Coenen, J. Moodysson, H. Martin, Path renewal in old industrial regions: Possibilities and limitations for regional innovation policy, Regional studies 49(5), 850 (2015)

4. M. Draskovic, D. Milica, I. Mladen, O. Chigisheva, Preference of institutional changes in social and economic development, J. of Int. Studies 10(2), 318 (2017)

5. P.J. Cárdenas-García, M. Sánchez-Rivero, J.I. Pulido-Fernández, Does tourism growth influence economic development? J. of Travel Research 54(2), 206 (2015)

6. A. Zaytseva, O. Brel, Ph. Kaizer, Russian Experience of Concervation and Renowation of Industrial Regions' Heritage, J. of Environmental Management and Tourism 4(28), 766 (2018) DOI:10.14505/jemt.v9.4(28).10

7. S. Fraser, Economic Diversification: A New Life Line for Lesser Developed Countries? Case Study of the OECS' Tourism Industry (2014)

8. L. G. Kiryanova, A.A. Surtseva, K.V. Yumatov, A.A. Pyatovsky, Tourism as a "poststaples» diversification for Russian remote resource-dependent regions: a new path for Kuzbass. Bulletin of the Tomsk Polytechnic University, Geo Assets Engineering 330(10), 230 (2019)

9. D. Kuznetsov, N. Rabkina, M. Ryabova, O. Valko, Coal-Mining Industry as a Forming Factor of Social, Cultural, and Linguistic Environment of Kuzbass as Resource Region of Siberia, E3S Web of Conferences, 105, 04040 (EDP Sciences, 2019)

10. D. Schmallegger, D.Carson, Is tourism just another staple? A new perspective on tourism in remote regions, Current Issues in Tourism, 13(3), 201 (2010)

11. S. Dołzbłasz, Post-Mining Regions in Central Europe - Problems, Potentials, Possibilities (oekom, München, 2012)

12. Strategiya sotsial'no-ekonomicheskogo razvitiya Kemerovskoy oblasti (KO) do 2035 goda, https://kemsu.ru/upload/Strategiya\%20KO\%202035.pdf?3 (in Russian)

13. S. Zhironkin, D. Khloptsov, N. Skrylnikova, I. Petinenko, O. Zhironkina, Economic Principles of Mining Region Sustainable Development, E3S Web of Conferences, 41, 04010 (EDP Sciences, 2018)

14. Nauchno-obrazovatel'nyy tsentr «Kuzbass». Napravleniya deyatel'nosti [Elektronnyy resurs]: available at: https://ноц42.pф/napravleniya (in Russian)

15. Territorialnyj organ Federalnojsluzhby gosudarstvennoj statistikipo Kemerovskoj oblasti. Oficialnaya statistika [Official statistics], available at: https://kemerovostat.gks.ru/ofstatistics (in Russian) 
16. F. Kaulich, Diversification vs. specialization as alternative strategies for economic development: Can we settle a debate by looking at the empirical evidence? (Vienna, 2012)

17. M. Ericsson, O. Löf, Mining's contribution to national economies between 1996 and 2016, Mineral Economics 32, 223 (2019)

18. Mining in rapid-growth economies (US Geological Survey Mineral Commodity Summaries, 2013) available at: https://www.ey.com/Publication/vwLUAssets/EY__Mining_in_rapid-growth_economies/\$FILE/EY-Mining-in-rapid-growtheconomies.pdf 